\title{
ANALISIS PENGARUH KUALITAS PELAYANAN TERHADAP KEPUASAN PELANGGAN DI CARIBOU COFFEE SARINAH
}

\author{
Antonius Rizki Krisnadi ${ }^{1)}$, Patrick Kurniawan ${ }^{2)}$ \\ 1) Program Studi Hospitality dan Pariwisata, Universitas Bunda Mulia \\ 2) Program Studi Hospitality dan Pariwisata, Universitas Bunda Mulia \\ 9 November 2018
}

\begin{abstract}
If a business have a good service quality, then the business can fulfill the customer satisfaction that directly can have an impact or affect the sales improvement or income of the business itself. This research was used quantitative methodology where number become the result of this research. The data in this research was collected by observation, questionnaire, and literature review. This research consist of two kinds of variable such as; independent variable (service quality) and dependent variable (customer satisfaction). Subject of this research was collected from 195 customers of Caribou Coffee Sarinah which randomly selected according to the criteria that already determined by the researcher or usually known as non-probability sampling technique.

From the result of this research, it can be conclude that the service quality viewed based on Realibility (X1) 0.534 has no significant effect to the customer satisfaction (Y). Service quality viewed based on Responsiveness (X2) 0.02 has a significant effect to the customer satisfaction (Y). Service quality viewed based on Assurance (X3) 0.10 has no significant effect to the customer satisfaction (Y). Service quality viewed based on Empathy (X4) 0.066 has no significance effect to the customer satisfaction (Y). Service quality viewed based on Tangible (X5) 0.000 has a significant effect to the customer satisfaction $(Y)$. The number of determination coefficient ( $R$ square) 0.500 equal $50 \%$. From the result, it can be conclude that the service quality variable $(X)$ has a significant effect to the customer satisfaction variable $(Y)$, and the rest was affected by other factors that was not discussed in this research.
\end{abstract}

Keyword: service quality, customer satisfaction, coffee shop

\begin{abstract}
ABSTRAK
Jika suatu bisnis memiliki kualitas pelayanan yang baik maka bisnis tersebut dapat memenuhi kepuasan pelanggannya yang secara langsung akan berdampak pada peningkatan sales/pendapatan bisnis itu sendiri. Penelitian ini mengunakan metode kuantitatif dimana metode ini mengunakan angka sebagai hasil penelitian. Data penelitian ini diperoleh melalui observasi, penyebaran kuisioner, dan studi pustaka. Pada penelitian ini variabel yang digunakan oleh peneliti adalah variabel independen $(\mathrm{X})$ yaitu kualitas pelayanan dan variabel dipenden (Y) yaitu kepuasaan pelanggan. Penyebaran kuisioner dalam penelitian ini dilakukan kepada 195 pelanggan yang dipilih secara acak sesuai kriteria peneliti atau biasanya disebut teknik non-probability sampling.

Dari penelitian ini dapat disimpulkan bahwa kualitas pelayanan dilihat dari Reliability (X1) sebesar 0.534 tidak berpengaruh secara signifikan terhadap kepuasan pelanggan (Y). Kualitas pelayanan dilihat dari Responsiveness (X2) sebesar 0.021 berpengaruh secara signifikan terhadap kepuasan pelanggan $(\mathrm{Y})$. Kualitas pelayanan dilihat dari Assurance (X3) sebesar 0.10 tidak berpengaruh secara signifikan terhadap kepuasan pelanggan (Y). Kualitas pelayanan dilihat dari Empathy (X4) sebesar 0.066 tidak berpengaruh secara signifikan terhadap kepuasan pelanggan (Y). Kualitas pelayanan dilihat dari Tangible (X5) sebesar 0.000 berpengaruh secara signifikan terhadap kepuasan pelanggan (Y). Besarnya nilai koefisien determinasi (R Square) 0.500 sama dengan 50\%. Angka tersebut memiliki arti bahwa variabel kualitas pelayanan (X) berpengaruh terhadap variabel kepuasaan pelanggan (Y) sebesar 50\%, sisa nya berarti dipengaruhi oleh faktor-faktor lain yang tidak dibahas pada penelitian ini.
\end{abstract}

Kata kunci: Kualitas pelayanan, kepuasan pelanggan, coffee shop. 


\section{PENDAHULUAN}

\section{1) Latar Belakang}

Bisnis di Indonesia secara umum tidak terlepas dari aktivitas produksi, pembelian, penjualan maupun pertukaran barang atau jasa yang melibatkan orang atau perusahaan. Menurut Kasmir dan Jakfar (2012,p7) bisnis adalah usaha yang dijalankan yang tujuan utamanya adalah keuntungan.

Banyak sekali jenis-jenis usaha yang dapat dijadikan bisnis di Indonesia, contoh nya adalah café. Café adalah sebuah tempat yang menyediakan tempat duduk didalam dan diluar ruangan. Café sendiri biasa enyediakan beragam jenis minuman seperti teh,kopi,jus ,coklat dan beberapa makanan ringan. Jadi café sendiri tidak terfokus kepada makanan berat.

Banyak kafe yang bermunculan sehingga membuat para owner berfikir lebih kreatif dalam pelayanan yang mereka berikan kekonsumen agar pelanggan mereka mencapai tingkat puas. Salah satu nya adalah Caribou Coffee Sarinah. Terletak di Jalan M.H Thamrin No 11, Jakarta Pusat. Caribou Coffee Sarinah merupakan salah satu kafe bertemakan kedai kopi yang menjual berbagai jenis minuman berupa kopi, teh, jus, dan beberapa makanan ringan seperti roti, kue, dan sandwich.

Berdasarkan tabel diatas terjadi penurunan terhadap penjualan dari bulan oktober 2017 hingga Februari 2018. Hal ini diperkuat berdasarkan observasi langsung lewat Guest Comment yang diberikan kepada tamu di Caribou Coffe. Dari hasil penyebaran Guest Comment banyak sekali yang menyatakan mengenai pelayanan yang diberikan oleh staff Caribou Coffe mengecewakan dan produk coffe tidak sesuai dengan yang dipesan.

Beberapa guest comment yang menyatakan bahwa kurangnya kualitas pelayanan yang dimiliki Caribou Coffee Sarinah sehingga mereka merasa tidak puas dengan pelayanan yang ada di Caribou Coffee Sarinah. Penting nya kualitas pelayanan terhadap pengunjung, menurut Parasurahman (2001) kualitas pelayanan dapat diukur melalui lima dimensi yaitu Reability, Responsiveness, Assurance, Empathy, dan Tangible. Pentingnya kualitas pelayanan yang sangat mempengaruhi kepuasan pelanggannya, sehingga penulis menarik kesimpulan terjadi penurunan kualitas pelayanan dari Caribou Coffee Sarinah sehingga menyebabkan penurusan sales yang cukup drastis

\section{2) Identifikasi Masalah}

Setiap penyedia jasa makanan dan minuman pasti memiliki standar pelayanan yang sudah ditetapkan oleh mereka sehingga penulis ingin meneliti apakah kualitas pelayanan di Caribou Coffee Sarinah sudah memuaskan pelanggannya. Karena dilihat dari data penjualan yang didapat, terjadi penuruan penjualan yang mengakibatkan penurunan penjualan sehingga menurut penulis turunnya penjualan ini disebabkan oleh ketidakpuasan pelanggan terhadap kualitas pelayanan yang diberikan oleh caribou coffee sarinah.

\section{3) Perumusan Masalah}

1. Apakah varabel Reability (X1) memiliki pengaruh terhadap kepuasan pelanggannya di Caribou Coffee Sarinah?

2. Apakah variabel Responsiveness (X2) memiliki pengaruh terhadap kepuasan pelanggannya di Caribou Coffee Sarinah?

3. Apakah variabel Assurance (X3) memiliki pengaruh terhadap kepuasan pelanggannya di Caribou Coffee Sarinah?

4. Apakah variabel Empathy (X4) memiliki pengaruh terhadap kepuasan pelanggannya di Caribou Coffee Sarinah?

5. Apakah variabel Tangible (X5) memiliki pengaruh terhadap kepuasan pelanggannya di Caribou Coffee Sarinah? 
6. Seberapa besar pengaruh variable kualitas pelayanan $(\mathrm{X})$ terhadap kepuasan $(\mathrm{Y})$ ?

\section{4) Tujuan dan Manfaat Penelitian}

Tujuan Penelitian ini adalah:

1. Untuk meningkatkan sistem pelayanan pada Caribou Coffe

2. Tujuan Fungsional dari penelitian ini yaitu agar hasil dari penelitian dapat dimanfaatkan sebagai referensi dasar untuk mengambil satu langka kebijakan dalam kualitas pelayanan di Caribou Coffee

\section{METODE PENELITIAN}

\section{Jenis Penelitian}

Jenis penelitian ini mengunakan metode mengambil metode analisis kuantitatif. Menurut DeFranzo (2011), penelitian kuantitatif untuk mengukur data yang berhubungan dengan angka atau data numeric dan data yang dapat dimodifikasikan hasilnya menjadi statistik. Peneliti menggunakan metode analisis kuantitatif karena hasil penelitian ini akan menggunakan angka sebagai hasil dari penelitian.

\section{Metode Penarikan Sampel}

Metode pengumpulan data dalam penelitian ini menggunakan:

\section{a. Observasi}

Menurut Moh.Nazir (2014:154) pengumpulan data dengan observasi adalah pengamatan langsung dengan cara pengambilan data dengan menggunakan mata tanpa pertolongan alat lain dengan perencanaan yang sistematis dan berkaitan dengan tujuan penelitian tersebut.

Dalam penelitian ini, penulis melakukan observasi di salah satu sosial media Zomato dengan melihat feedback yang diberikan oleh pelanggan Caribou Coffee Sarinah.

\section{b. Kuesioner}

Menurut Business Dictionary (2017), kuesioner adalah alat untuk membantu peneliti untuk mengumpulkan data untuk survey yang akan ditanyakan kepada objek penelitian yang berisikan beberapa pertanyaan spesifik dan informasi lengkap yang akan dibutuhkan dalam penelitian berdasarkan tujuan dari penelitian tersebut.

Dalam penelitian ini peneliti menyebarkan kuisioner tertutup dimana daftar pertanyaan yang alternatif jawabannya sudah disediakan yang itu sangat tidak setuju, tidak setuju, netral, setuju dan sangat setuju.

\section{c. Studi Pustaka}

Studi Pustaka adalah terknik pengumpulan data atau kajian teroritis, dan referensi yang berkaitan dengan nilai dan norma yang berkembang pada situasi sosial yang diteliti (Sugiyono: 2012)

Dalam penelitian ini studi pustaka yang dilakukan penulis bertujuan untuk mencari teoriteori yang dapat menjelaskan penelitian ini.

\section{Populasi}

Penulis menyimpulkan bahwa populasi adalah wilayah yang diambil oleh peneliti untuk diteliti dan ditarik kesimpulan pada akhirnya. Populasi pada penelitian ini meliputi seluruh pengunjung yang datang ke mall Sarinah.

\section{Sampel}

Sampel yang diambil dalam penelitian ini berupa perwakilan dari populasi yaitu pelanggan Caribou Coffee Sarinah. Mengacu pada pernyataan dari Hair dkk dalam Prawira (2010:46) bahwa jumlah sampel sebagai responden adalah 5 kali dari jumlah pertanyaan yang terdapat dalam kuisioner. Indikator dalam penelitian ini terdiri dari 1 variabel bebas 5 subvariabel bebas dan 1 variabel 5 subvariabel terikat. Total pertanyaan dalam penelitian ini adalah 39 pertanyaan sehingga minimal ukuran sampel penelitian ini adalah 39 × $5=195$ responden.

Cara pengambil sampel peneliti menggunakan teknik nonprobability. Menurut Sugiyono (2016:82) Non probability sampling adalah teknik pengambilan sampel yang tidak memberi peluang atau kesempatan sama bagi setiap unsur atau anggota populasi untuk dipilih menjadi sampel. Teknik sampel ini meliputi, sampling 
sistematis, kuota, aksidental, purposive, jenuh, snowball.

Alasan peneliti mengambil teknik nonprobability sampling karena peniliti ingin mengambil sampel sesuai dengan kriteria yang harus dipenuhi dan pertimbangan-pertimbangan.

\section{Metode Analisis}

\section{Metode Pengujian Validitas dan Reliabilitas}

\section{Uji Validitas}

Pengertian validitas menurut Sugiyono (2010:267) adalah :

"Derajat ketetapan antara data yang terjadi pada objek penelitian dengan daya yang dapat dilaporkan oleh penelitian. Dengan demikian data yang valid adalah data "yang tidak berbeda" antara data yang dilaporkan oleh peneliti dengan data yang sesungguhnya terjadi pada objek penelitain."

\section{Uji Reliabilitas}

Uji reliabilitas menurut Sugiyono (2010:354) dilakukan untuk mengetahui apakah hasil pengukuran konsisten bila dilakukan lebih dari satu kali atau berkali-kali dengan mengunakan alat ukur yang sama.

\section{Uji Linearitas}

Menurut Lela (2011:49) mengemukakan bahwa Uji linearitas adalah metode dimana penguji dapat mengetahui dua variabel mempunyai hubungan linear yang signifikan atau tidak.Pengujian ini melihat bagaimana variabel (X) mempengaruhi variabel (Y).

\section{Analisis Deskriptif Data Penelitian}

Metode deskriptif Sugiyono (2009:35) adalah penelitian yang dilakukan untuk mengetahui keberadaan variabel mandiri, baik hanya pada satu variabel atau lebih (variabel yang berdiri sendiri) tanpa membuat perbandingan dan mencari hubungan variable itu dengan variabel yang lain
Metode verifikastif Sugiyono (2009:13) dapat diartikan sebagai metode penelitian yang berlandaskan pada filsafat positivism, digunakan untuk meneliti pada populasi atau sampel tertentu dengan tujuan untuk menguji hipotesis yang telah ditetapkan.

Penulis menggunakan metode tersebut, karena penilitian ini ditunjukan untuk menggambarkan dengan jelas bagaimana pengaruh kualitas pelayanan terhadap kepuasan pelanggan di Caribou Coffee Sarinah. Data yang diperlukan adalah data yang sesuai dengan masalah-masalah yang ada dan sesuai dengan tujuan penelitian, sehingga dapat diketahui mengenai pengaruhnya dengan berdasarkan teori dan pengujian hipotesis.

\section{Rancangan Pengujian Hipotesis}

\section{Uji t (Uji parsial)}

Uji t adalah metode dimana kita melihat seberapa besar variabel independen mempengaruhi variabel dipenden.Terdapat 2 cara dalam pengujian $t$ dengan kriteria sebagai berikut:

Jika thitung $>\mathrm{t}$ table maka ho ditolak, sebalik nya jika $\mathrm{t}$ hitung $<\mathrm{t}$ table maka ho diterima atau mengunakan kriteria lainnya yaitu jika $\mathrm{p}<0.05$ maka ho ditolak sebalik nya jika $\mathrm{p}>0.05$ maka ho diterima

\section{Uji F}

Ghazali (2012:98) Menyebutkan bahwasanya uji Simultan (Uji-F) pada dasarnya menunjukkan apakan semua variable independen yang dimasukan dalam model mempunyai pengaruh secara bersama-sama terhadap variable dependen ataukah tidak.

\section{Koefisien Determinasi}

Menurut Nawari (2010) Koefisen Determinasi digunakan untuk mengukur kemampuan variabel independen dalam menjelaskan variabel dipenden dengan nilai koefisien determinasi menyatakan proporsi keragaman pada variabel 
bergantung yang mampu dijelaskan oleh variabel penduganya.

\section{HASIL DAN PEMBAHASAN}

Identitas Responden

1. Jenis Kelamin

TABEL 1

Jenis Kelamin

\begin{tabular}{ccc}
$\begin{array}{c}\text { Jenis } \\
\text { kelamin }\end{array}$ & Frekuensi & $\begin{array}{c}\text { Persantase } \\
(\%)\end{array}$ \\
\hline Pria & 83 & $43 \%$ \\
\hline Wanita & 112 & $57 \%$ \\
\hline Total & 195 & $100 \%$
\end{tabular}

Sumber: data di olah oleh peneliti (2018)

2. Umur

\section{TABEL 2}

\section{Umur Responden}

$\begin{array}{ll}\text { Umur Frekuensi } & \begin{array}{l}\text { Persentase } \\ (\%)\end{array}\end{array}$

\begin{tabular}{lll}
\hline $17-25$ & 145 & $74,36 \%$ \\
\hline $26-40$ & 44 & $22,57 \%$ \\
\hline$>40$ & 6 & $3,07 \%$ \\
\hline Total & 195 & $100 \%$
\end{tabular}

Sumber: data di olah oleh peneliti (2018)

3. Pekerjaan
Pekerjaan Responden

\begin{tabular}{lll} 
Pekerjaan & $\begin{array}{l}\text { Frekuens } \\
\text { i }\end{array}$ & $\begin{array}{l}\text { Persentas } \\
\text { e }(\%)\end{array}$ \\
\hline $\begin{array}{l}\text { Sma/Mahasiswa } \\
\text { /i }\end{array}$ & 87 & $44,62 \%$
\end{tabular}

\begin{tabular}{lll}
\hline $\begin{array}{l}\text { Karyawan } \\
\text { Swasta }\end{array}$ & 88 & $45,13 \%$ \\
\hline
\end{tabular}

\begin{tabular}{lll}
\hline Wirausaha & $\mathbf{1 0}$ & $\mathbf{5 , 1 3 \%}$ \\
\hline PNS/BUMN & 3 & $1,54 \%$ \\
\hline Lain-lain & 7 & $3,58 \%$ \\
\hline Total & 195 & $100 \%$
\end{tabular}

Sumber: data di olah oleh peneliti (2018)

4. Penghasilan

Tabel 4.

Penghasilan Responden

Penghasilan Frekuensi Persentase (\%)

\begin{tabular}{lll}
\hline$<$ Rp & 69 & $35,38 \%$ \\
3.000 .000 & &
\end{tabular}

\begin{tabular}{lll}
\hline $\begin{array}{ll}\text { Rp } \\
\text { 3.000.000 - }\end{array}$ & 69 & $35,38 \%$ \\
$\begin{array}{l}\text { Rp } \\
\text { 4.999.999 }\end{array}$ & & \\
\hline $\begin{array}{l}\text { Rp } \\
\text { 5.000.000 - }\end{array}$ & & \\
$\begin{array}{l}\text { Rp } \\
10.000 .000\end{array}$ & & $20,52 \%$ \\
\hline$>$ Rp & 17 & $8,72 \%$ \\
10.000 .000 & & \\
\hline Total & 195 & $100 \%$
\end{tabular}

Sumber: data di olah oleh peneliti (2018)

5. Frekuensi kunjungan pelanggan Caribou

Coffee Sarinah dalam satu bulan 


\section{Tabel 5}

Frekuensi kunjungan pelanggan

\begin{tabular}{lll}
$\begin{array}{l}\text { Kunjungan } \\
\text { dalam 1 }\end{array}$ & Frekuensi & $\begin{array}{l}\text { Persentase } \\
(\%)\end{array}$ \\
bulan & & \\
\hline
\end{tabular}

\begin{tabular}{lll}
\hline 1-2 kali & 117 & $60 \%$ \\
\hline 3-4 kali & 29 & $14,83 \%$ \\
\hline $4-6$ kali & 24 & $12,33 \%$ \\
\hline$>6$ kali & 25 & $12,84 \%$ \\
\hline Total & 195 & $100 \%$
\end{tabular}

Sumber : data diolah oleh peneliti (2018)

Uji Validitas dan Uji Reliabilitas

Uji Validitas

Tabel 6

Rekapitulasi Hasil Uji Validitas Variabel Sub Variabel Reliabilitas/Reliability (X1)

Butir Pertanyaan
r hitung

\begin{tabular}{lccl}
\hline R1 & 0.563 & 0.3 & Valid \\
\hline R2 & 0.655 & 0.3 & Valid \\
\hline R3 & 0.595 & 0.3 & Valid \\
\hline R4 & 0.492 & 0.3 & Valid \\
\multicolumn{4}{l}{ Sumber : hasil pengelolaan data SPSS (2018) }
\end{tabular}

Tabel 7

Rekapitulasi Hasil Uji Validitas Variabel Sub Variabel Responsif/Responsive (X2)

\begin{tabular}{lrrl}
$\begin{array}{c}\text { Butir } \\
\text { Pertanyaan }\end{array}$ & r hitung & r kritis & keterangan \\
\hline RE1 & 0.568 & 0.3 & Valid \\
\hline RE2 & 0.66 & 0.3 & Valid \\
\hline RE3 & 0.647 & 0.3 & Valid
\end{tabular}
RE4
0.616
0.3 Valid
Sumber : hasil pengelolaan data SPSS (2018)

\section{Tabel 8}

\section{Variabel Sub Variabel Jaminan/Assurance (X3)}

Butir
Pertanyaan hitung

\begin{tabular}{llll}
\hline A1 & 0.647 & 0.3 & Valid \\
\hline A2 & 0.621 & 0.3 & Valid \\
\hline A3 & 0.617 & 0.3 & Valid \\
\hline A4 & 0.646 & 0.3 & Valid \\
\hline
\end{tabular}

Sumber : data diolah oleh peneliti (2018)

\section{Tabel 9}

\section{Rekapitulasi Hasil Uji Validitas Variabel} Sub Variabel Empati/Empathy (X4)

\begin{tabular}{|c|c|c|c|}
\hline $\begin{array}{c}\text { Butir } \\
\text { Pertanyaan }\end{array}$ & r hitung & r kritis & keterangan \\
\hline
\end{tabular}

\begin{tabular}{lccl}
\hline E1 & 0.657 & 0.3 & Valid \\
\hline E2 & 0.709 & 0.3 & Valid \\
\hline E3 & 0.673 & 0.3 & Valid \\
\hline E4 & 0.585 & 0.3 & Valid \\
\multicolumn{4}{l}{ Sumber : data diolah oleh peneliti } \\
(2018)
\end{tabular}

\section{Tabel 10}

Rekapitulasi Hasil Uji Validitas Variabel Sub Variabel Nyata/Tangible (X5)

Butir
Pertanyaan hitung

\begin{tabular}{llll}
\hline T1 & 0.594 & 0.3 & Valid \\
\hline T2 & 0.572 & 0.3 & Valid \\
\hline T3 & 0.641 & 0.3 & Valid \\
\hline T4 & 0.685 & 0.3 & Valid
\end{tabular}


Sumber : data diolah oleh peneliti (2018)

Tabel 11

Rekapitulasi Hasil Uji Validitas Variabel Sub Variabel Repeat (Y1)

Butir
Pertanyaan

\begin{tabular}{lrrl}
\hline REP1 & 0.585 & 0.3 & Valid \\
\hline REP2 & 0.477 & 0.3 & Valid \\
\hline REP3 & 0.54 & 0.3 & Valid
\end{tabular}

Sumber : data diolah oleh peneliti (2018)

Tabel 12

Rekapitulasi Hasil Uji Validitas Variabel Sub Variabel Rekomendasi/ Recommendation (Y2)

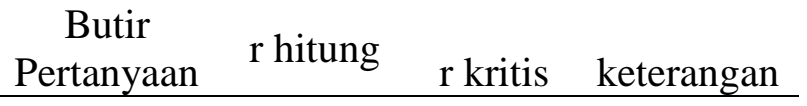

\begin{tabular}{llrl}
\hline REC1 & 0.613 & 0.3 & Valid \\
\hline REC2 & 0.711 & 0.3 & Valid \\
\hline REC3 & 0.663 & 0.3 & Valid \\
\hline REC4 & 0.571 & 0.3 & Valid \\
Sumber -data diolah oleh peneliti & (2018) & \\
\end{tabular}

Tabel 13

\section{Rekapitulasi Hasil Uji Validitas Variabel Sub Variabel Loyal (Y3)}

\begin{tabular}{|c|c|c|c|}
\hline $\begin{array}{c}\text { Butir } \\
\text { Pertanyaan }\end{array}$ & r hitung & r kritis & keterangan \\
\hline
\end{tabular}

\begin{tabular}{llll}
\hline L1 & 0.516 & 0.3 & Valid \\
\hline L2 & 0.459 & 0.3 & Valid \\
\hline L3 & 0.506 & 0.3 & Valid \\
\hline L4 & 0.527 & 0.3 & Valid
\end{tabular}

Sumber : data diolah oleh peneliti (2018)

Tabel 14
Rekapitulasi Hasil Uji Validitas Variabel Sub Variabel Trust (Y4)

Butir
Pertanyaan hitung r kritis keterangan

\begin{tabular}{lrrl}
\hline TR1 & 0.633 & 0.3 & Valid \\
\hline TR2 & 0.54 & 0.3 & Valid \\
\hline TR3 & 0.642 & 0.3 & Valid \\
\hline TR4 & 0.575 & 0.3 & Valid \\
Sumber : data diolah oleh peneliti (2018) &
\end{tabular}

\section{Tabel 15}

\section{Variabel Sub Variabel Inovasi/Innovation} (Y5)

Butir
Pertanyaan hitung r kritis keterangan

\begin{tabular}{llll}
\hline I1 & 0.477 & 0.3 & Valid \\
\hline I2 & 0.475 & 0.3 & Valid \\
\hline I3 & 0.486 & 0.3 & Valid \\
\hline I4 & 0.583 & 0.3 & Valid \\
Sumber : data diolah oleh peneliti (2018) &
\end{tabular}

Berdasarkan tabel-tabel diatas semua hasil uji karena $\mathrm{t}$ hitung $>0.3$, dapat dikatakan bahwa semua variable dinyatakan Valid.

\section{Uji Reliabilitas}

Koefisien reliabilitas butir pernyataan pada kuesioner masing-masing variabel $>0,6$.Sesuai dengan teori dari Sugiyono (2010) dapat disimpulkan bahwa seluruh variabel andal (reliable) dalam mengukur variabel nya.

\section{Uji T}

Pengujian hipotesis parsial (Uji-t)

\section{Tabel 16}

\section{Hasil Uji T}

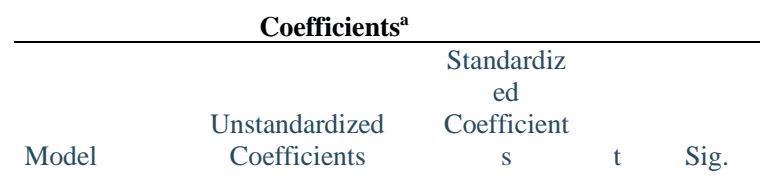




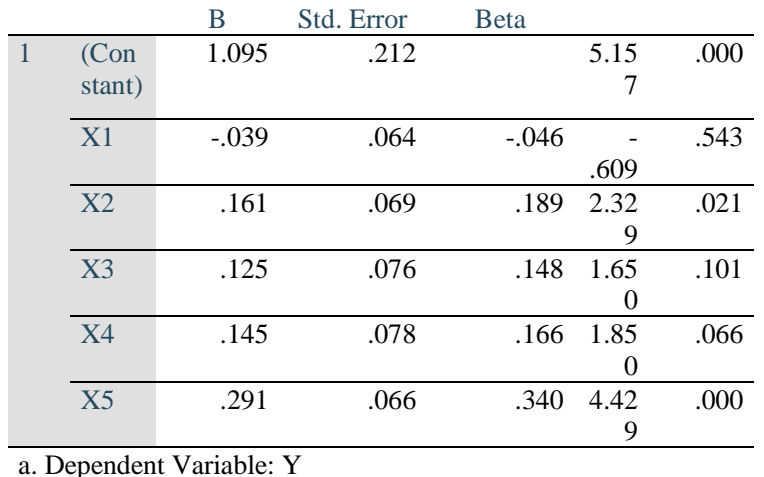

\section{Coefficients $^{\mathbf{a}}$}

Sumber: hasil pengelolaan data SPSS (2018)

\section{Pengujian hipotesis parsial sub variabel}

\section{Reliabilitas/Reliability(X1)}

Dari data diatas diperoleh nilai probabilitas signifikan X1 sebesar 0.543. Dikarenakan nilai probabilitas signifikan $\mathrm{X} 1>0.05$ maka $\mathrm{H}_{\mathrm{o}}$ diterima dan $\mathrm{H}_{1}$ ditolak, dapat disimpulkan bahwa variabel independen (X1) tidak berpengaruh secara signifikan terhadap variabel dipenden $(\mathrm{Y})$.

\section{Pengujian hipotesis parsial sub variabel}

\section{Responsif/Responsive (X2)}

Dari data diatas diperoleh nilai probabilitas signifikan X2 sebesar 0.02. Dikarenakan nilai

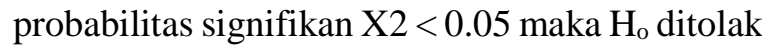
dan $\mathrm{H}_{1}$ diterima, dapat disimpulkan bahwa varibel independen (X1) berpengaruh secara signifikan terhadap varibel dipenden $(\mathrm{Y})$.

\section{Pengujian hipotesis parsial sub variabel Jaminan/Assurance (X3)}

Dari data diatas diperoleh nilai probabilitas signifikan X3 sebesar 0.10. Dikarenakan nilai probabilitas signifikan $\mathrm{X} 3>0.05$ maka $\mathrm{H}_{\mathrm{o}}$ diterima dan $\mathrm{H}_{1}$ ditolak, dapat disimpulkan bahwa variabel independen (X3) tidak berpengaruh secara signifikan terhadap variabel dipenden $(\mathrm{Y})$.

\section{Pengujian hipotesis parsial sub variabel Empati/Empathy (X4)}

Dari data diatas diperoleh nilai probabilitas signifikan X4 sebesar 0.066. Dikarenakan nilai probabilitas signifikan $\mathrm{X} 4<0.05$ maka $\mathrm{H}_{\mathrm{o}}$ ditolak dan $\mathrm{H}_{1}$ diterima, dapat disimpulkan bahwa variabel independen (X4) tidak berpengaruh secara signifikan terhadap variabel dipenden $(Y)$.

\section{Pengujian hipotesis parsial sub variabel Nyata/Tangible (X5)}

Dari data diatas diperoleh nilai probabilitas signifikan X5 sebesar 0.000. Dikarenakan nilai

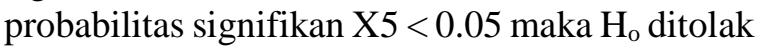
dan $\mathrm{H}_{1}$ diterima, dapat disimpulkan bahwa variabel independen (X5) berpengaruh secara signifikan terhadap variabel dipenden $(\mathrm{Y})$.

\section{Uji F}

Hasil pengujian hipotesis secara simultan adalah sebagai berikut:

\section{Tabel 17}

\section{Hasil Uji F}

\begin{tabular}{|c|c|c|c|c|c|c|}
\hline \multicolumn{7}{|c|}{ ANOVA $^{\mathrm{a}}$} \\
\hline & & Sum of & & Mean & & \\
\hline \multicolumn{2}{|c|}{ Model } & Squares & df & Square & $\mathrm{F}$ & Sig. \\
\hline \multirow[t]{3}{*}{1} & $\begin{array}{l}\text { Regres } \\
\text { sion }\end{array}$ & 24.301 & 5 & 4.860 & 37.731 & $.000^{\mathrm{b}}$ \\
\hline & $\begin{array}{l}\text { Residu } \\
\text { al }\end{array}$ & 24.346 & 189 & .129 & & \\
\hline & Total & 48.646 & 194 & & & \\
\hline
\end{tabular}

a. Dependent Variable: Y

b. Predictors: (Constant), X5, X1, X2, X4, X3

Sumber:hasil pengelolaan data SPSS (2018)

Berdasarkan output diatas, nilai sig $(0.00)<\alpha$ (0.05) maka ho ditolak, artinya variabel independen /variabel bebas berpengaruh secara signifikan terhadap varibel dipenden/variabel terikat.

\section{Koefisien determinasi}

Koefisien determinasi digunakan untuk melihat persentase kontribusi pengaruh variabel 
independen $(\mathrm{X})$ terhadap variabel dipenden $(\mathrm{Y})$. Nilai yang digunakan pada uji ini adalah nilai $R$ square

\section{Table 18}

\section{Hasil Uji Koefisiensi Determinasi}

\begin{tabular}{lr|r|r|r|r}
\multicolumn{7}{c}{ ANOVA $^{\text {a }}$} \\
\multicolumn{1}{c}{$\begin{array}{c}\text { Sum of } \\
\text { Model }\end{array}$} & $\begin{array}{r}\text { Mean } \\
\text { Squares }\end{array}$ & df & Square & F & Sig. \\
\hline $1 \quad \begin{array}{l}\text { Regres } \\
\text { sion }\end{array}$ & 24.301 & 5 & 4.860 & 37.7 & $.000^{\mathrm{b}}$ \\
\hline $\begin{array}{l}\text { Residu } \\
\text { al }\end{array}$ & 24.346 & 189 & .129 & & \\
\hline Total & 48.646 & 194 & & & \\
\hline
\end{tabular}

a. Dependent Variable: $Y$

b. Predictors: (Constant), X5, X1, X2, X4, X3

Sumber : hasil pengelolaan data SPSS (2018)

Dari data diatas dapat disimpulkan bahwa variabel independen $(\mathrm{X})$ berpengaruh secara signifikan terhadap variabel dipenden (Y) dilihat dari nilai signifikan $<0.05$.

\section{Tabel 19}

\section{Hasil Uji Koefisiensi Determinasi} Model Summary

\begin{tabular}{|c|c|c|c|c|}
\hline Model & $\mathrm{R}$ & $\begin{array}{c}\mathrm{R} \\
\text { Square }\end{array}$ & $\begin{array}{c}\text { Adjusted } \\
\text { R } \\
\text { Square }\end{array}$ & $\begin{array}{l}\text { Std. Error } \\
\text { of the } \\
\text { Estimate }\end{array}$ \\
\hline 1 & $.707^{a}$ & .500 & .486 & .35890 \\
\hline
\end{tabular}

a. Predictors: (Constant), X5, X1, X2, X4, X3

Sumber : hasil pengelolaan data SPSS (2018)

Dari data diatas diketahui nilai $\mathrm{R}$ Square sebesar 0.500 . Besarnya nilai koefisien determinasi ( $R$ Square) 0.500 sama dengan 50\%. Angka tersebut memiliki arti bahwa variabel Kualitas Pelayanan (X) berpengaruh terhadap variabel Kepuasaan Pelanggan (Y) sebesar 50\%, sisa nya berarti dipengaruhi oleh faktor-faktor lain yang tidak dibahas pada penelitian ini.

Menurut Sugiyono (2012) jika nilai koefisien determinasi di angka 36-63.99\% maka pengaruh antar variabel tersebut dinyatakan kuat.

\section{SIMPULAN}

Berdasarkan hasil perhitungan dan analisis dibab sebelumnya, dapat disimpulkan bahwa:

1. Kepuasan pelanggan dilihat dari sub variabel Reliabilitas/Reliability(X1) tidak berpengaruh terhadap kepuasan pelanggan di Caribou Coffee Sarinah karena nilai probabilitas signifikan X1 sebesar 0.543.Dikarenakan pelayanan dari Caribou Coffee Sarinah belum bisa memenuhi seluruh kebutuhan pelanggannya dan juga tidak memberikan produk yang sesuai dengan apa yang mereka janjikan.

2. Kepuasan pelanggan dilihat dari sub variabel Responsif/Responsive(X2) berpengaruh terhadap kepuasan pelanggan di Caribou Coffee Sarinah karena nilai probabilitas signifikan X2 sebesar 0.02.Dikarenakan pelayanan di Caribou Coffee Sarinah cepat dalam membuat dan memberikan produk kepada pelanggannya dan juga memiliki system pelayanan yang efisien dalam arti pelanggan langsung memesan dikasir dan minumannya langsung bisa diambil kurang dari 3 menit.

3. Kepuasan pelanggan dilihat dari sub variabel Jaminan/Assurance (X3) tidak berpengaruh terhadap kepuasan pelanggan di Caribou Coffee Sarinah karena nilai probabilitas signifikan X3 sebesar 0.10.Dikarenakan kurangnya pengetahuan tentang produk dan ilmu Hospitality dari pelayanan di Caribou Coffee Sarinah yang harus diberi pelatihan ulang.

4. Kepuasan pelanggan dilihat dari sub variabel Empati/Empathy (X4) tidak berpengaruh terhadap kepuasaan pelanggan di Caribou Coffee Sarinah karena nilai probabilitas signifikan $\mathrm{X} 4$ 
sebesar 0.066. Dikarenakan kurangnya koneksi terhadap tamu dan juga kurangnya perhatian dalam memenuhi kebutuhan pelanggannya.

5. Kepuasan Pelanggan dilihat dari sub variabel Nyata/Tangible (X5) berpengaruh terhadap kepuasaan pelanggan di Caribou Coffee sarinah karena nilai probabilitas signifikan X5 sebesar 0.000. Dikarenakan fasilitas dari Caribou Coffee Sarinah sudah mampu memuaskan pelanggannya, dalam segi interior, fasilitas pendukung seperti toilet, lahan parkir, AC, smoking room, dan juga tata letak ruangan dari segi kebersihan sudah baik. Penggunaan alatalat kopi yang modern juga mendukung kepuasan pelanggan di Caribou Coffee Sarinah.

Kualitas Pelayanan berpengaruh signifikan terhadap Kepuasan Pelanggan di Caribou Coffee Sarinah dengan total pengaruh $50 \%$ sedangkan sisanya di pengaruhi oleh faktor-faktor lain di luar penelitian ini. Menurut Sugiyono (2012) bila nilai $\mathrm{r}$ square 0.5 maka pengaruh kualitas pelayanan terhadap kepuasan pelanggan dinyatakan kuat. Karena dunia retail sangat dipengaruhi oleh pelayanan khususnya dunia jasa makanan dan minuman. Namun tidak hanya kualitas pelayanan yang dibutuhkan agar membentuk bisnis yang menguntungkan, ada faktor-faktor lain yang berperan selain kualitas pelayanan, bisa dari harga,promosi dan lain-lain.

\section{DAFTAR PUSTAKA}

Arikunto, S. (2010). Prosedur Penelitian Suatu Pendekatan Praktik. Jakarta: Rineka Cipta.

A, Parasuraman. (2001). The Behaviorial Consequense s of Service Quality, Jurnal of Marketing . Vol 60.

Danang, Sunyoto. (2012). Manajemen Sumber Daya Manusia . Jakarta: PT Buku Seru.

Fandy, Tjiptono . (2011). Service Management Mewujudkan Layanan Prima. Edisi 2. Yogyakarta: Andi.
Ghozali, I. (2012). Aplikasi Analisis Multivariate dengan Program IBM SPSS. Yogjakarta: Universitas Diponegoro.

Handy, I. (2002). Prinsip Kepuasan Pelanggan. Jakarta: Elix Media Komputindo.

Jakfar, K. d. (2012). Studi Kelayakan Bisnis. Jakarta: Kencana.

Kotler, Philip dan Kevin L. Keller. (2009).Manajemen Pemasaran terj: Bob Sabran. Edisi 13 Jilid 1 dan 2. Erlangga :Jakarta

Nawari. (2010). Analisis Regresi dengan Ms Excel 2017 dan SPSS 17. jakarta: Gava Media.

Sugiyono. (2009). Metode Penelitian Kuantitatif dan Kualitatif . Bandung CV. Alfabeta.

Sugiyono. (2010). Metodologi Penelitian Administrasi . Jakarta : CV. Alfabeta.

Sugiyono. 2012. Metode Penelitian Kuantitatif Kualitatif dan R\&D . Bandung: Alfabeta.

Sugiyono. (2016). Metodologi Penelitian Kuantitatif, Kualitatif, dan R\&D. Bandung: CV Alfabeta.

Tjiptono, Fandy, (2008), Strategi Pemasaran, Edisi 3, ANDI: Yogyakar 